\title{
ANALISIS HUBUNGAN MOTIVASI TERHADAP KINERJA PEGAWAI (Studi Kasus Pada Kantor Kecamatan Ruing Kabupaten Ngada NTT)
}

\author{
RAIS DERA PUA RAWI \\ E-mail: Raisdera207@gmail.com \\ Pengajar di Prodi Manajemen Fak.Ekonomi.Universitas Muhammadiyah Sorong \\ Diterima:17 Januari 2017. Disetujui:18 Februari 2017. Dipublikasikan:1 Maret 2017
}

\begin{abstract}
This study aims to determine the Relationship Motivation Against Employees Performance at the Office District Riung Ngada NTT, both partially and to determine which variables are most dominantly related to employee performance. Approach used in this study is Cross Sectional Study, with research type is research Analytical Survey .. Population as well as samples in this study as many as 30 employees at the district office Riung Ngada district NTT.The results showed that (1) There is a significant relationship incentive with the performance of employees at the district office Riung Ngada NTT. This is indicated by Chi-square value 4,176 3,841. (2) No significant relationship Allowance with employee performance at the Rinung sub-district office Ngada NTT.Hal is shown with the value of Chi-square 0,517 <3.841. (3) There is no significant correlation of reward with employee performance at Riung District office of Ngada District NTT.Hal is shown by Chi-square $2,308<3,841$. The statistic test with Chi-square shows that incentives are highly related to $4.176 \%$. As for the variable allowance of 0,517\% and the variable of appreciation 2,308\%, these two variables are not related to employee performance.
\end{abstract}

Keywords: Incentives, Benefits, rewards, and employee performance.

\section{PENDAHULUAN}

Peranan pemerintah dalam meningkatkan kesejahteraan umum terutama dalam memberikan pelayanan kepada masyarakat merupakan keharusan yang bersifat mutlak. Maka aparatur pemerintah dalam memberikan pelayanan kepada masyarakat umum dituntut untuk melaksanakannya secara profesional dan berkelanjutan agar masyarakat dapat memberikan pandangan positif yang ditimbulkan oleh perasaan puas dalam diri masyarakat.

Pengelolaan sumber daya manusia tidak lepas dari faktor pegawai yang diharapkan dapat berprestasi sebaik mungkin demi mencapai tujuan kantor pemerintah. Pegawai merupakan aset 
utama kantor dan mempunyai peran yang strategis di dalam kantor atau instansi yaitu sebagai pemikir, perencana, dan pengendali aktivitas kantor. Demi tercapainya tujuan kantor, pegawai memerlukan motivasi untuk bekerja lebih rajin. Melihat pentingnya pegawai dalam kantor, maka pegawai diperlukan perhatian lebih serius terhadap tugas yang dikerjakan sehingga tujuan kantor tercapai.

Menurut Danim (2004:4) mengatakan bahwa "Motivasi adalah sesuatu kekuatan dorongan, kebutuhan, semangat, tekanan atau mekanisme psikolog yang mendorong seseorang kelompok orang untuk mencapai prestasi tertentu sesuai dengan apa yang dikehendakinya".

Menurut Malthis (2006:114), motivasi adalah keinginan dalam diri seseorang yang menyebabkan orang tersebut bertindak. Menurut Robert kreitner dan angelo kinicki(2011:205) motivasi merupakan proses psikologis yang membangkitkan dan mengarahkan perilaku pada pencapaian tujuan atau goal-directed behavior.

Sedangakn Stephen P.Robbins (2003:156) menyatakan motivasi sebagai proses yang menyebabakn intensitas(intensity), arah (direction),dan usaha terus menerus(persistence) individu menuju pencapaian tujuan.Dari pendapatpendapat tersebut diatas dapat disimpulkan bahwa motivasi merupakan doronagan terhadap serangkaian proses perilaku manusia pada pencapaian tujuan.Menurut Rachmawati (2004:176) mengemukakan bahwa "Motivasi merupakan faktor-faktor yang mempengaruhi diri dalam mengarahkan dan menggerakkan individu untuk menciptakan tujuan tertentu".

Penelitian yang dilakukan oleh Sartika Hayulinanda Halim dengan judul "Analisis Pengaruh Motivasi dan Lingkungan Kerja Terhadap Kinerja Karyawan Pada PT.Sinar Galesong Pratama Makassar". Penelitian ini bertujuan untuk mengetahui apakah motivasi dan lingkungan kerja mempunyai pengaruh terhadap kinerja karyawan pada PT. Sinar Galesong Pratama Makassar. Hasil analisis menunjukkan bahwa: 1) hasil analisis mengenai faktor yang mempengaruhi kinerja karyawan menunjukkan bahwa faktor motivasi memiliki hubungan yang positif terhadap kinerja karyawan yang 
ditunjukkan dengan koefisien variabel dimana faktor motivasi bertanda positif, sedangkan faktor lingkungan kerja memiliki hubungan yang positif terhadap kinerja karyawan. 2) dari hasil analisis mengenai faktor-faktor yang mempengaruhi kinerja karyawan nampak bahwa antara kedua variabel yang dianalisis, maka yang paling dominan mempengaruhi kinerja karyawan adalah variabel lingkungan kerja. Hal tersebut dibuktikan dengan hasil perhitungan thitung masing-masing variabel dimana thitung lingkungan kerja $(8,237)$ lebih besar dibandingkan dengan nilai t-hitung motivasi kerja sebesar 2,080.Indikator dalam mengoptimalkan motivasi terhadap pegawai antara lain: pemberian intensif, pemberian tunjangan dan penghargaan. Dengan motivasi kerja yang tinggi, pegawai akan bekerja lebih giat di dalam melaksanakan pekerjaannya. Sebaliknya dengan motivasi kerja yang rendah pegawai tidak mempunyai semangat bekerja, mudah menyerah, dan kesulitan dalam menyelesaikan pekerjaannya.

\section{Hubungan Antara Motivasi dan} Kinerja Pegawai
Motivasi merupakan hasrat didalam diri seseorang yang menyebabkan orang tersebut melakukan tindakan. Seseorang sering melakukan tindakan untuk suatu hal demi mencapai tujuan. Motivasi mempersoalkan bagaimana caranya mendorong gairah kerja bawahan, agar mereka mau bekerja keras dengan memberikan semua kemampuan dan keterampilannya untuk mewujudkan tujuan perusahaan.

$$
\text { Mangkunegara }
$$
menyatakan faktor yang mempengaruhi kinerja adalah faktor kemampuan dan faktor motivasi. Sementara Malthis (2007), menyatakan kinerja yang dicari oleh perusahaan dari seseorang tergantung dari kemampuan, motivasi, dan dukungan individu yang diterima. Menurut Munandar (2001) bahwa ada hubungan positif antara motivasi dan kinerja dengan pencapaian prestasi, artinya karyawan yang mempunyai motivasi dan prestasi yang tinggi cenderung mempunyai kinerja yang tinggi, sebaliknya mereka yang mempunyai kinerja rendah dimungkinkan karena motivasinya rendah.

Penelitian Suharto dan Budhi Cahyono (2005) juga menguji hubungan 
motivasi dengan kinerja karyawan, bahwa motivasi kinerja berpengaruh positif terhadap kinerja karyawan.

Berdasarkan analisis hasil penelitian ini menunjukan bahwa motivasi kerja yang dimiliki setiap pegawai berpengaruh positif dan signifikan terhadap kinerja pegawai.

\section{Faktor-faktoryang Mempengaruhi}

\section{Kinerja}

Menurut Kuswandi (2004:27) ada beberapa yang mempengaruhi kinerja pegawai atau karyawan, antara lain sebagai berikut:

a. Kepuasaan pegawai, Kepuasaan pegawai merupakan salah satu faktor yang sangat penting untuk mendapatkan hasil pekerjaan yang optimal. Kepuasaan pegawai mencerminkan perasaan seseorang terhadap pekerjaannya. Ketika seseorang mersakan kepuasaan dalam bekerja, tentunya ia akan berupaya semaksimal mungkin dengan segenap kemampuan yang dimiliki untuk menyelesaikan tugas pekerjaannya. Dengan demikian kinerja dari hasil pegawai akan meningkat secara optimal. b. Kemampuan pegawai. Kinerja individual pegawai juga dipengaruhi oleh kemampuan yang dimiliki oleh karyawan itu sendiri. Karyawan dengan kemampuan teknis maupun operasional yang tinggi untuk sebuah tugas akan meningkatkan semangat kerjanya. Seseorang pegawai atau kary awan merasa termotivasi dan memiliki kinerja yang baik, jika ia memiliki pengetahuan yang memadai terhadap bidang tugas dan tanggungjawabnya. Oleh karena itu, pimpinan hendaknya melakukan sesuatu upaya untuk meningkatkan pengetahuan karyawan baik melalui pendidikan formal maupun pelatihan, akses informasi dan pengalaman.

c. Kepemimpinan (Leadership). Dalam kehidupan organisasi, instansi atau perusahaan, kepemimpinan memang berperan penting dalam usaha mencapai tujuan yang telah ditetapkan. Baik 5tidaknya suatu kepemimpinan akan menetukan kinerja pegawai atau karyawan. Kepemimpinan Yang menggairahkan pegawainya merupakan sumber motivasi, sumber semngat dan sumber disiplin dalam melaksanakan tugas yang menjadi 
tanggung jawab mereka. Oleh karena itu, instansi yang ingin sukses harus menunjukkan kepemimpinan yang baik kepada karyawan, atau pegawai bawahannya dan memiliki semangat yang tinggi untuk mencapai tujuan organisasi.

d. Motivasi. Keberhasilan pengelolaan organisasi, instansi atau perusahaan sangat ditentukan oleh efektivitas kegiatan pendayagunaan sumber daya manusia. Oleh karena itu, pimpinan memiliki tekhnik-tekhnik untuk dapat memelihara dan mempertahankan kinerja pegawai, salah satu dengan memberikan motivasi kepada pegawai atau personil agar dapat berkerja secara optimal.

e. Lingkungan kerja. Terciptanya lingkungan kerja baik fisik maupun non fisik yang kondusif merupakan faktor yang memelihara kontribusi besar dalam meningkatkan kepuasan kerja pegawai. Lingkungan kerja nyaman bagi pegawai dapat meningkatkan kinerja. Sebaliknya lingkungan kerja yang tidak memadai akan dapat menurunkan kinerja dan akhirnya menurunkan motivasi kerja pegawai.

\section{Analisis Metode}

Jenis penelitian yang digunakan adalah survey Analitik dengan pendekatan Cross Sectional Study, Yaitu jenis penelitian untuk melihat hubungan antara variabel Dependent dan variabel independent.

Penelitian ini dilakukan dengan mengumpulkan data-data kualitatif, yang selanjutnya akan disajikan dalam bentuk angka (dikuantifikasikan) untuk diuji secara verifikatif sesuai dengan rancangan analisis data.

Adapun tehnik analisis data yang digunakan dalam penelitian ini adalah sebagai berikut:

1. Analisis data secara Univariat dimaksudkan untuk menganalisis tiap tiap variabel dari hasil penelitian tentang data yang meliputi rata-rata, dan standar deviasi.

2. Analisis secara Bivariat digunakan untuk menguji hipotesis-hipotesis penelitian dengan menggunakan uji korelasi.

3. Analisis secara multivariat digunakan untuk memungkinkan kita melakukan penelitian lebih dari dua variabel secara bersamaan. 


\section{Jurnal Noken 2 (2)15-28 2017}

\section{Hasil}

Hasil analisis data disajikan dalam

bentuk tabel dilengkapi dengan

penjelasan sebagai berikut:

Tabel 2.2.Distribusi Jenis Kelamin Pegawai Kantor Kecamatan Riung Kabupaten Ngada

Nusa Tenggara Timur Tahun 2015

\begin{tabular}{|c|c|c|}
\hline Jenis kelamin & Frekuensi & Persentase \\
\hline Laki-laki & 25 & 83,3 \\
Perempuan & 5 & 16,7 \\
\hline Jumlah & 30 & 100,0 \\
\hline
\end{tabular}

Sumber:Data Primer,2015

Tabel 2.2. diatas menunjukan

bahwa jumlah pegawai pada kantor

kecamatan Riung kabupaten Ngada

Nusa Tenggara Timur (NTT) sebanyak

b. Tingkat Pendidikan

Tabel 2.3. Distribusi Tingkat Pendidikan Pegawai Pada Kantor Kecamatan Riung Kabupaten Ngada Nusa Tenggara Timur Tahun 2015

\begin{tabular}{|c|c|c|}
\hline Tingkat pendidikan & Frekuensi & Persentase \\
\hline SMP & 4 & 13,3 \\
SMA/SEDERAJAT & 19 & 63,3 \\
PERGURUAN TINGGI & 7 & 23,3 \\
\hline Jumlah & 30 & 100,0 \\
\hline
\end{tabular}

Sumber:Data primer,2015

Tabel 2.3.di atas menunjukan bahwa tingkat pendidikan pegawai pada kantor kecamatan Riung kabupaten Ngada Nusa Tenggara Timur,memiliki beda,diantaranya untuk tingkat SMP adalah 13,3\%,SMA/Sederajat 63,3\%,dan untuk perguruan tinggi sebesar 23,3\%.

c. Insentif
1. Analisis Univariat

a. Jenis kelamin
30 orang dengan rincian jenis kelamin laki-laki $83.3 \%$,dan jenis kelamin perempuan $16,7 \%$. 


\section{Jurnal Noken 2 (2)15-28 2017}

\begin{tabular}{|c|c|c|}
\hline Cukup & 8 & 26,7 \\
Kurang & 22 & 73,3 \\
\hline Jumlah & 30 & 100,0 \\
\hline
\end{tabular}

Sumber:Data Primer 2015

Tabel 2.4 diatas menunjukan sedangkan yang mengatakan kurang bahwa insentif pegawai yang didapat oleh memenuhi kebutuhan adalah sebesar 73,3 pegawai kantor kecamatan Riung belum $\%$. memenuhi kebutuhannya dimana yang d. Tunjangan mengatakan cukup hanya $26,7 \%$

Tabel 2.5.Distribusi Tunjangan pegawai kecamatan Riung Kabupaten NgadaNusa

Tenggara Timur Tahun 2015

\begin{tabular}{|c|c|c|}
\hline Tunjangan & Frekuensi & Persentase \\
\hline Cukup & 29 & 96,7 \\
Kurang & 1 & 3,3 \\
\hline Jumlah & 30 & 100,0 \\
\hline
\end{tabular}

Sumber:Data Primer 2015

Tabel 2.5 diatas menunjukan bahwa Tunjangan yang diberikan kepada cukup sebesar 96,7 \% dan dikatakan pegawai kantor kecamatan ruing dapat kurang sebesar 3,3\%. memenuhi kebutuhan dimana dikatakan Tabel 2.6.Distribusi penghargaan pegawai pada kantor kecamatan Riung Kabupaten Ngada Nusa Tenggara Timur Tahun 2015

\begin{tabular}{|c|c|c|}
\hline Penghargaan & Frekuensi & Persentase \\
\hline Baik & 20 & 86,7 \\
Kurang & 10 & 13,3 \\
\hline Jumlah & 30 & 100,0 \\
\hline
\end{tabular}

Sumber:Data primer 2015

Tabel 2.6di atas menunjukan bahwa penghargaan yang diberikan kepada pegawai kantor memiliki persentase yang baik sebesar $86,7 \%$ dan kurang sebesar $13,3 \%$.

Tabel 2.7.Distribusi kinerja pegawai pada kantor kecamatan Riung Kabupaten Ngada Nusa

Tenggara Timur Tahun 2015

\begin{tabular}{l|l|l} 
Kinerja Pegawai & Frekuensi & Persentase \\
\hline
\end{tabular}




\section{Jurnal Noken 2 (2)15-28 2017}

\begin{tabular}{|c|c|c|}
\hline Baik & 20 & 66,7 \\
Kurang & 10 & 33,3 \\
\hline Jumlah & 30 & 100,0 \\
\hline
\end{tabular}

Sumber:Data Primer 2015

Tabel 2.7.Diatas menunjukan

bahwa kinerja pegawai baik sebesar $66,6 \%$ dan kurang sebesar $33,3 \%$.

2. Analisis Bivariat a. Hubungan Insentif terhadap Kinerja pegawai pada kantor kecamatan Riung Kabupaten Ngada Nusa Tenggara Timur.

Tabel 2.8.Hubungan Insentif Terhadap Kinerja Pegawai Pada Kantor Kecamatan Riung Kabupaten Ngada Nusa Tenggara Timur Tahun 2015

\begin{tabular}{|c|c|c|c|c|c|c|}
\hline \multirow{2}{*}{ Insentif } & \multicolumn{4}{|c|}{ Kinerja Pegawai } & \multirow{2}{*}{ Kumlah } & $\begin{array}{c}\text { Chi } \\
\text { Square } \\
\left(X^{2}\right)\end{array}$ \\
\cline { 2 - 5 } & \multicolumn{2}{|c|}{ Baik } & Fums & & \\
\cline { 2 - 6 } & Frekuensi & Persentase & Frekuensi & Persentase & & \\
Cukup & 3 & 37,5 & 5 & 62,5 & 8 & \multirow{2}{*}{4,176} \\
Kurang & 17 & 77,3 & 5 & 22,7 & 22 & \\
\hline Jumlah & 20 & 66,7 & 10 & 33,3 & 30 & \\
\hline
\end{tabular}

Sumber:Data primer 2015

Tabel 2.8 menunjukan bahwa dari 8 pegawai yang memiliki insentif cukup terdapat yang kinerja baik sebanyak $37,5 \%$,sedangkan dari 22 pegawai yang memiliki insentif kurang sebanyak $77,3 \%$.

Hasil analisis statistic diperoleh nilai chi square $(4,176) \geq 3,841$.berarti Tabel 2.9.Hubungan Tunjangan Terhadap Kinerja Pegawai Pada Kantor Kecamatan Riung Kabupaten Ngada Nusa Tenggara Timur Tahun 2015

\begin{tabular}{|c|c|c|c|c|c|c|}
\hline \multirow{2}{*}{ Tunjangan } & \multicolumn{4}{|c|}{ Kinerja pegawai } & \multirow{2}{*}{ Kumlah } & $\begin{array}{c}\text { Chi } \\
\text { square } \\
\left(\mathrm{x}^{2}\right)\end{array}$ \\
\cline { 2 - 5 } & \multicolumn{3}{|c|}{ Baik } & \multicolumn{2}{c|}{ Kurang } & \\
\cline { 2 - 6 } Cukup & 19 & 65,5 & 10 & 34,5 & 29 & \\
kurang & 1 & 100,0 & 0 & 0,0 & 1 & \multirow{2}{*}{0,517} \\
\hline Jumlah & 20 & 66,7 & 10 & 33,3 & 30 & \\
\hline
\end{tabular}

terdapat hubungan antara insentif dengan kinerja pegawai.

b. Hubungan Tunjangan terhadap kinerja pegawai pada kantor kecamatan Riung Kabupaten Ngada Nusa Tenggara Timur Tahun 2015 
Sumber:Data Primer 2015

Tabel 2.9 menunjukan bahwa dari 29 pegawai yang memiliki Tunjangan cukup terdapat yang kinerja baik sebanyak $65,5 \%$,sedangkan dari 1 pegawai yang memiliki Tunjangan kurang sebanyak 100,0\%.

Hasil analisis statistic diperoleh nilai chi square $(0,517)<3,841$.berarti tidak terdapat hubungan antara Tunjangan dengan kinerja pegawai.

c. Hubungan Penghargaan terhadap kinerja pegawai pada kantor kecamatan Riung kabupaten Ngada (NTT) Tahun 2015.

Tabel 2.10.Hubungan Penghargaan Terhadap Kinerja Pegawai Pada Kantor Kecamatan

Riung Kabupaten Ngada Nusa Tenggara Timur Tahun 2015

\begin{tabular}{|c|c|c|c|c|c|c|}
\hline \multirow{2}{*}{ Penghargaan } & \multicolumn{4}{|c|}{ Kinerja pegawai } & \multirow{2}{*}{$\begin{array}{c}\text { Chi } \\
\text { Numlah }\end{array}$} & $\begin{array}{c}\text { Kquare } \\
\left(\mathrm{x}^{2}\right)\end{array}$ \\
\cline { 2 - 6 } & Frekuensi & persentase & Frekuensi & Persentase & & \\
\cline { 2 - 6 } Baik & 16 & 61,5 & 10 & 38,5 & 26 & \\
kurang & 4 & 100,0 & 0 & 0,0 & 4 & 2,308 \\
\hline Jumlah & 20 & 66,7 & 10 & 33,3 & 30 & \\
\hline
\end{tabular}

Sumber:Data Primer 2015

Tabel 2.10.Menunjukan bahwa dari

26 pegawai yang memiliki Penghargaan Baik terdapat yang kinerja baik sebanyak $61,5 \%$,sedangkan dari 4 pegawai yang memiliki Penghargaan kurang sebanyak $100,0 \%$.
Hasil analisis statistic diperoleh nilai chi square $(2,308)<3,841$. Berarti tidak terdapat hubungan antara Penghargaan dengan kinerja pegawai.

3. Analisis Multivariat

Tabel 2.11.Analisis Multivariat Terhadap Kinerja Pegawai Pada Kantor Kecamatan Riung Kabupaten Ngada Nusa Tenggara Timur Tahun 2015

\begin{tabular}{|c|c|c|c|c|c|c|}
\hline \multirow{2}{*}{ VARIABEL } & \multirow{2}{*}{ B } & S.E. & \multirow{2}{*}{ Df } & \multirow{2}{*}{$\operatorname{Sig}$} & \multirow{2}{*}{$\operatorname{Exp}(\mathrm{B})$} & \multicolumn{2}{|c|}{\begin{tabular}{c} 
E5,0\% C.I.for \\
\cline { 4 - 5 }
\end{tabular}} & & & & & Lower & Upper \\
\hline
\end{tabular}




\section{Jurnal Noken 2 (2)15-28 2017}

\begin{tabular}{|c|c|c|c|c|c|c|c|}
\hline INSENTIF & $-1,735$ & 0,890 & 1 & 0,051 & 0,176 & \multirow{2}{*}{0,031} & 1,010 \\
Constant & 2,245 & 1,547 & 1 & 0,147 & 9,444 & & \\
\hline
\end{tabular}

Sumber:Data Primer,2015 


\section{Jurnal Noken 2 (2)15-28 2017}

Tabel 2.11.Menunjukan bahwa dari hasil uji regresi logistic dimana dari ketiga variabel independen variabel insentif memiliki nilai chi-square $(4,176)$ dan nilai chi-square< 3,841, hal ini berarti bahwa variabel insentif merupakan variabel yang paling berhubungan dibandingkan dengan variabel lainnya .Dan variabel insentif sangat berpengaruh ,176 kali terhadap keberhasilan kinerja pegawai kantor.

\section{Pembahasan}

Hasil analisis uji statistik menunjukkan bahwa variabel insentif berpengaruh terhadap tingkat keberhasilan kinerja pegawai kantor,sedangkan variabel Tunjangan dan Penghargaan tidak berhubungan atau tidak berpengaruh terhadap tingkat keberhasilan kinerja pegawai kantor kecamatan Riung Kabupaten Ngada Flores Nusa Tenggara Timur (NTT).

\section{1) Insentif}

Hasil penelitian menunjukan bahwa Insentif yang diberikan kepada pegawai belum dapat memenuhi kebutuhan,dimana dari 8 pegawai yang memiliki insentif cukup,terdapat yang kinerjanya baik sebesar $37,5 \%$,dan dari 22 pegawai yang memiliki insentif kurang sebanyak 77,3\%.apabila hal ini dihubungkan dengan kinerja pegawai maka dari 8 pegawai yang memiliki insentif baik dan tedapat kinerja pegawainya baik sebesar /-pol;.62,5\%,sedangkan dari 22 pegawai yang memiliki insentif kurang dan jika dihubungkan dengan variabel kinerja pegawai terdapat $22,7 \%$.

Hasil analisis statistic menunjukan bahwa ada hubungan antara variabel insentifvariabel kinerja pegawai dengan nilai chi-square $(4,176) \geq 3,841$.Dengan hasil analisis ini insentif yang diberikan kepada pegawai sangat berberhubungan terhadap kinerja pegawai.

\section{2) Tunjangan}

Hasilpenelitian menunjukan bahwa Tunjangan yang diberikan kepada pegawai belum dapat memenuhi kebutuhan,dimana dari 29 pegawai yang memiliki Tunjangan cukup,terdapat yang kinerjanya baik sebesar $65,5 \%$,dan dari 1 pegawai yang memiliki Tunjangan kurang sebanyak 100,0\%.apabila hal ini dihubungkan dengan kinerja pegawai maka dari 29 pegawai yang memiliki Tunjangan baik dan tedapat kinerja pegawainya baik sebesar $34,5 \%$,sedangkan dari 1 pegawai yang memiliki Tunjangan kurang dan jika dihubungkan dengan variabel kinerja pegawai terdapat $0,0 \%$.

Hasil analisis statistic menunjukan bahwa ada hubungan antara variabel Tunjangan variabel kinerja pegawai dengan nilai chi-square $(0,517)<3,841$.Dengan hasil analisis ini insentif yang diberikan kepada 


\section{Jurnal Noken 2 (2)15-28 2017}

pegawai tidak berberhubungan terhadap kinerja pegawai.

\section{3) Penghargaan}

Hasil penelitian menunjukan bahwa Penghargaan yang diberikan kepada pegawai belum dapat dikatakan baik,dimana dari 26 pegawai yang memiliki Penghargaan baik,terdapat yang kinerjanya baik sebesar $61,5 \%$,dan dari 4 pegawai yang memiliki Penghargaan kurang sebanyak 100,0\%.apabila hal ini dihubungkan dengan kinerja pegawai maka dari 26 pegawai yang memiliki Penghargaan baik dan tedapat kinerja pegawainya baik sebesar $38,5 \%$,sedangkan dari 4 pegawai yang memiliki Penghargaan kurang dan jika dihubungkan dengan variabel kinerja pegawai terdapat $0,0 \%$.

Hasil analisis statistic menunjukan bahwa ada hubungan antara variabel Penghargaan variabel kinerja pegawai dengan nilai chi-square $(2,308)<$ 3,841.Dengan hasil analisis ini Penghargaan yang diberikan kepada pegawai tidak berberhubungan terhadap kinerja pegawai.

\section{Penutup}

Sesuai dari hasil analisis statistik dengan berdasarkan pada masalah yang diajukan, maka dapat ditarik kesimpulan sebagai berikut:
1) Ada hubungan yang signifikan antara insentif dengan kinerja pegawai pada kantor kecamatan Riung Kabupaten Ngada NTT.

2) Tidak ada hubungan yang signifikan antara Tunjangan dengan kinerja pegawai pada kantor kecamatan Riung Kabupaten Ngada NTT.

3) Tidak ada hubungan yang signifikan antara penghargaan dengan kinerja pegawai pada kantor kecamatan Riung kabupaten Ngada NTT.

4) Hasil Analisis Multivariat variabel Insentif memiliki hubungan yang paling kuat terhadap tingkat keberhasilan kinerja pegawai pada kantor kecamatan Riung kabupaten Ngada NTT.

Dari hasil penelitian ini ada beberapa rekomendasi dan saran yang perlu diperhatikan, yaitu:

1) Penelitian ini dapat dikembangkan oleh praktisi dan akademisi sebagai bahan masukan untuk mendesain kinerja, dengan menanyai langsung atau dengan data sekunder agar data diperoleh lebih akurat.

2) Bagi peneliti selanjutnya diharapkan dapat memanfaatkan dan mengembangkan hasil penelitian ini dengan menggunakan variabel yang berbeda atau indikator yang digunakan 
pada masing-masing variabel perlu dikembangkan. Selain itu penelitian ini hanya dilakukan pada salah satu kantor kecamatan, oleh karena itu diperlukan sikap kehati-hatian dalam mengeneralisasi hasil penelitian ini pada instansi pemerintahan yang berbeda.

3) Bagi peneliti lain dengan paradigma kuantitatif namun bertujuan memahami obyek yang bersifat kontekstual, subyektif dan informal, metode penelitian ini dapat disempurnakan dengan integrasi metodologis yang lebih baik. Pengembangan teori kontekstual dengan pendekatan kuantitatif masih perlu disempurnakan agar elemenelemen mendasar dari obyek yang dipahami lebih akurat dan baik.

4) Diharapkan kepada pihak instansi agar dalam melakukan pekerjaan sesuai dengan tanggung jawab yang telah di amanahkan demi tercapainya tujuan yang diinginkan.

\section{DAFTAR PUSTAKA}

Arifin (2005) Pengaruh Motivasi dan Kemampuan kerja terhadap Kinerja dan Kepuasan kerja karyawan PT Satu Nusa Persada Batam.

Ghozali, Imam. 2001. Aplikasi Analisis Multivariate Dengan Program SPSS Badan Penerbit Undip, Semarang.
Haminati Sharikha, Aan Permana, 2012. "Pengaruh Pemberian Insentif Terhadap Kinerja Pustakawan Di Perpustakaan Daerah Provinsi Jawa Tengah. ’Diakses September 2012.

Handoko.T. Hani. 2001. Manajemen Personalia dan SDM. Yogyakarta: BPFE.

Hasibuan, S. P. Malayu. 2003. Manajemen Sumber Daya Manusia. Jakarta: Bumi Aksara.

H.Jakson, Faktor-faktor yang mempengaruhi Kinerja 2001.

Ismail,Sukidarfi.(2003).HubunganKemampu andanMotivasiDenganKinerjaPegawai Pusat Penelitian dan Pengembangan Departemen Kehakimandan HAM RI.Depok: Universitas Indonesia.

Mangkunegara, Prabu. 2002. Manajemen Sumber Daya Manusia Perusahaan, Cetakan ke-2. Bandung : PT. Remaja Rosdakarya Offset.

Nawawi Handani, 2008,MetodePenelitian Ekonomi, Erlangga, Jakarta.

Robert L, Malthis \& Jhon H. Lackson 2002. Manajemen Sumber Daya Manusia, (Bisnis, Manajemen, keuangan, dan SDM). Edisi 9. Jakarta :Salemba Siagian, Sondang P. 2002. Kiat Meningkatkan Prestasi Kerja. Jakarta : Rineka Cipta. 


\section{Jurnal Noken 2 (2)15-28 2017}

Ruky, Achmad. 2002. Sistem Manajemen

Kinerja. Jakarta: Gramedia Pustaka Utama

Sasmita. 2002. Demokrasi dan Falsafah Pemimpin adalah untuk Bawahannya.

Sedarmayanti. S. 2004. Good Governance (kepemimpinan yang baik).

Sugiyono, 2003. Metode Penelitian Administrasi, Bandung Alfabeta .

-------, 2009. Memahami Penelitian Kualitatif. Bandung: Al Fabeta.

Wibowo. 2009. Manajemen Kinerja. Jakarta: Raja Grapindo Persada. 